\title{
Improvement of Reactivity of Carbon Iron Ore Composite with Biomass Char for Blast Furnace
}

\author{
Shigeru UEDA, Kentaro WATANABE, Kazunari YANAGIYA, Ryo INOUE and Tatsuro ARIYAMA \\ Institute of Multidisciplinary Research for Advanced Materials, Tohoku University, 2-1-1 Katahira Sendai, Miyagi $980-8577$ \\ Japan.
}

(Received on April 16, 2009; accepted on June 5, 2009)

\begin{abstract}
Enhancement of reactivity of the burden in the blast furnace can decrease the reducing agent of blast furnace. Besides high reactivity coke, the carbon iron ore composite is considered to be a typical high reactivity burden that can control the thermal reserve zone temperature. Since the reactivity of biomass char is much higher than that of coke, the use of carbon iron ore composite with biomass char will be favorable for decreasing the reducing agent. In the present study the reaction and reducing behavior of the carbon iron ore composite with biomass char were investigated. The gasification rate of biomass char was measured in $\mathrm{CO}_{2}$ atmosphere, and the reaction rate equation of that was derived. The microscopic structure change of biomass during carbonization was experimentally analyzed. According to the experimental results, the reduction of the composite begins at about $550^{\circ} \mathrm{C}$ in an inert gas atmosphere, and it is much lower than the composite with coke. Analysis of the reaction of carbon iron ore composite was carried out with the reaction model of the carbon iron ore composite based on a lumped system, in which the reaction rate of biomass char and iron ore were installed. The reaction model shows that the biomass char can improve the reduction behavior of the carbon iron ore composite especially in the lower temperature region. Moreover, the influence of gas atmosphere and the optimum structure of the composite were investigated by the model calculation to estimate the optimum condition of the composite in the blast furnace.
\end{abstract}

KEY WORDS: biomass char; carbon iron ore composite; mathematical model; carbon gasification; blast furnace; carbon dioxide; ironmaking.

\section{Introduction}

Low reducing agent operation of blast furnaces is an effective method of decreasing carbon dioxide emission. ${ }^{1,2}$ The consumption of reducing agents in blast furnaces can be decreased by a decreasing the ratio of $\mathrm{CO}$ and $\mathrm{CO}_{2}$ in top gas and the thermal reserve zone temperature in the blast furnace. Since the thermal reserve zone temperature is mainly determined by the heat balance between the endothermic gasification reaction of coke and the heat supply from gas flow, enhancement of the reaction rate of coke leads to the low reducing agent operation of blast furnaces.

The carbon iron ore composite is composed of fine powder coke and iron ore, which are in close contact with each other. Therefore, reactivity of that is much higher than that of conventional burden for the blast furnace operation. ${ }^{3-6)}$ In the previous paper, it was confirmed that the gasification reaction of the carbon determines reduction reaction rate of the carbon iron ore composite. ${ }^{7-10)}$ Enhancement of gasification reaction in the carbon iron ore composite would cause higher reactivity of it and decreases temperature of the thermal reserve zone. ${ }^{4)}$ Acceleration of gasification of coke with adding some element with catalytic effect had been investigated. ${ }^{3)}$ Basically, the reactivity of biomass char produced with carbonization of biomass is much higher than that of coke. ${ }^{11,12)}$ Using the biomass char as a reducing agent in the carbon iron ore composite may cause the high reactivity of the composite. In order to study the reactivity of biomass char, it should be considered that the character of biomass char depends on the condition of carbonization. The optimum condition of carbonization of biomass must be clarified.

In the present study, reaction behavior of the carbon iron ore composite with biomass char in the blast furnace was investigated. The gasification reaction rate of the biomass char was measured in $\mathrm{CO}_{2}$ atmosphere and the relationship between the reaction rates and properties of biomass chars with various carbonization conditions were discussed.

Finally, the reaction analysis of the carbon iron ore composite was carried out on the basis of the reaction model of the carbon iron ore composite, in which the measured reaction rates of biomass char and iron ore were installed.

\section{Production of the Biomass Char with Carbonization of Biomass}

\subsection{Biomass Pretreatment}

Woody biomass is mainly composed of cellulose and lignin. The cellulose forms the structure of wood. The reducing agent used in carbon iron ore composite should be fine particles, meanwhile the cellulose causes low grind ability of biomass. Therefore, raw biomass is difficult to be 
used as reducing agent in the composite. Decomposition temperature ranges of cellulose and hemicellulose are from 250 to $400^{\circ} \mathrm{C}$ and from 180 to $300^{\circ} \mathrm{C}$, respectively. ${ }^{13)}$ If biomass is carbonized in over the temperature ranges, the structure of cellulose would be decomposed and the grind ability of that would be improved. In the present study, carbonization of biomass over $400^{\circ} \mathrm{C}$ in an inert gas was employed as the pretreatment method of biomass char.

\subsection{Carbonization of Biomass}

Carbonization of biomass was carried out over $400^{\circ} \mathrm{C}$ at an inert gas, namely Ar atmosphere. Lumber of Japanese cedar was used as a biomass. That was cut into a piece of $10 \mathrm{~mm} \times 10 \mathrm{~mm} \times 50 \mathrm{~mm}$. In order to consider of heat pattern for carbonization, two initial conditions for heating were employed, (1) Hot start condition; the biomass was charged into heated furnace at the specified temperature, and (2) Cold start condition; after charging the biomass into the furnace, the sample heated with increasing temperature at a rate of $0.167^{\circ} \mathrm{C} / \mathrm{s}$. For both condition, after reaching the specified temperature, the biomass was kept in the furnace for $7200 \mathrm{~s}$.

The composition of raw biomass used in the present experiment and biomass chars carbonized in various temperatures were listed in Table 1. Concentration of $\mathrm{C}, \mathrm{H}$ and $\mathrm{N}$ in organic substance, and ash were analyzed and concentration of $\mathrm{O}$ was determined from the mass balance. The composition for biomass chars also were plotted in Fig. 1. Where, the horizontal and vertical axes represent mole fraction ratio of $\mathrm{O} / \mathrm{C}$ and $\mathrm{H} / \mathrm{C}$, respectively. Open circle (Hot) and solid circle (Cold) denote the sample carbonized with the Hot and Cold start conditions, respectively. Lignin contained in the biomass char carbonized at $400^{\circ} \mathrm{C}$ was not decomposed completely, therefore the sample contains relatively high hydrogen and oxygen in concentration. However, the concentration of hydrogen and oxygen in the sample decrease with an increasing in temperature of carbonization, some parts of hydrogen in the char carbonized at $1000^{\circ} \mathrm{C}$ still remains about 0.1 in the ratio of $\mathrm{H} / \mathrm{C}$. Influence of heating pattern, namely, the Hot and Cold start conditions on the composition of the chars was not clear.

Production yield of the biomass char related to the raw biomass is shown in Fig. 2. The production yield of sample with the Cold start condition is higher than that with the Hot start condition. At the temperature range in lower than $400^{\circ} \mathrm{C}$, cellulose and lignin decompose with complex reactions of dehydration, decarbonation, and demethanation. The decomposition of cellulose and lignin with the Cold start condition causes less recovery ratio than that with the rapid heating condition. The deviation between the conditions increases with increasing in carbonization temperature over $600^{\circ} \mathrm{C}$. Rapid heating increases gasification of biomass and decrease production ratio of the char.

\subsection{Gasification Reaction Rate of Fine Particle of Bio- mass Char}

The thermogravimetric method was employed to measure the weight change of fine biomass char particles during reaction with $\mathrm{CO}_{2}$ gas at $1 \mathrm{~atm}$. Biomass char produced in the Sec. 2.2 was employed as the sample for the present experiment. The biomass char was ground in an agate mortar and
Table 1. Composition of raw biomass used in the present experiment and biomass chars carbonized in various conditions.

\begin{tabular}{c|cccc}
\hline \multicolumn{5}{c}{ Ultimate analysis (mass\%) } \\
\hline & $\mathrm{C}$ & $\mathrm{H}$ & $\mathrm{O}$ & Ash \\
\hline Japanese Cedar & 48.3 & 5.93 & 45.1 & 0.66 \\
\hline Cold 400 & 81.2 & 3.63 & 14.1 & 0.81 \\
\hline Cold 600 & 94.2 & 1.81 & 2.78 & 1.08 \\
\hline Cold 800 & 95.1 & 1.05 & 2.05 & 1.57 \\
\hline Cold 1000 & 95.8 & 0.86 & 1.94 & 0.87 \\
\hline Hot 400 & 84.9 & 3.39 & 10.8 & 0.74 \\
\hline Hot 600 & 92.6 & 2.10 & 4.07 & 0.98 \\
\hline Hot 800 & 93.9 & 1.38 & 3.20 & 1.32 \\
\hline Hot 1000 & 94.4 & 1.31 & 2.42 & 1.42 \\
\hline
\end{tabular}

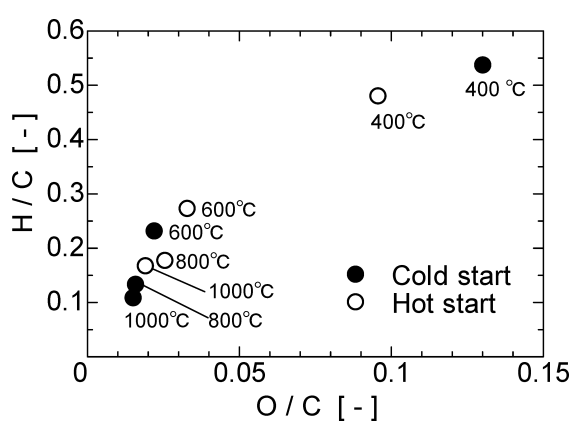

Fig. 1. Chemical composition of biomass char.

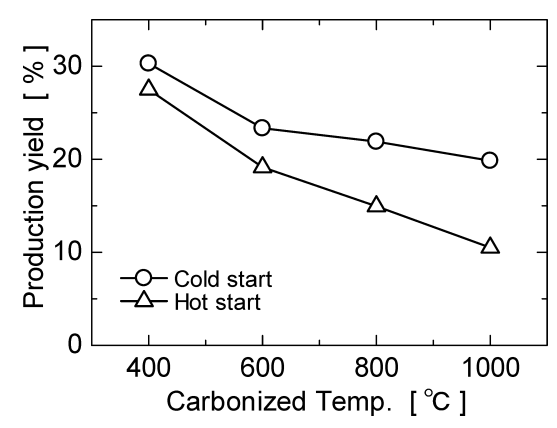

Fig. 2. Production yield of biomass char with various carbonization conditions.

the particle diameter was controlled by screening. A platinum crucible ( $5 \mathrm{~mm}$ diameter, $2.5 \mathrm{~mm}$ height) was used as a container; to prevent the occurrence of gas diffusion-limited reaction of coke, about $0.4 \mathrm{mg}$ of biomass char particles were distributed thinly and uniformly on the bottom. Initially, the atmosphere of the reaction chamber was filled with the $\mathrm{CO}_{2}$ gas, and then the temperature was increased to the measurement temperature at a rate of $1.67^{\circ} \mathrm{C} / \mathrm{s}$. After reaching the specified temperature, the reaction ratio was immediately measured. The weight change decreases with an increase in the reaction ratio; therefore, the measurement was done before the reaction ratio reached 0.15 . Due to the presence of volatile matter in the biomass char carbonized at 400 and $600{ }^{\circ} \mathrm{C}$, a weight change could be observed that is larger than the actual reaction ratio. The measurements were carried out only for sample carbonized at 800 and $1000^{\circ} \mathrm{C}$. The amount of volatile matter was considered smaller than the weight change associated with the gasification reaction; therefore, the influence of volatile matter was 


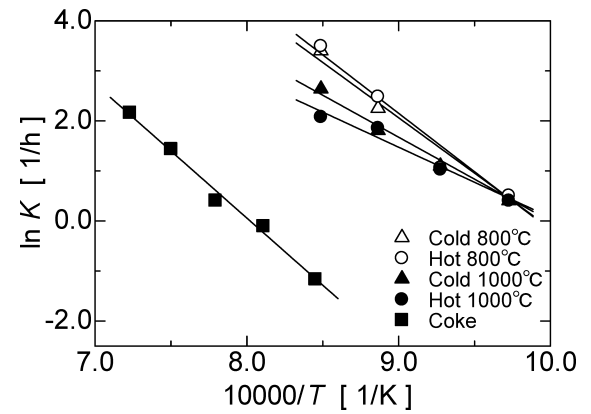

Fig. 3. Rate constant of gasification reaction of biomass char and coke particle in $\mathrm{CO}_{2}$.

treated as negligible. The rate constant of gasification reaction was defined as initial weight change rate of sample at specific temperature. The relationship between the rate constant of gasification reaction of biomass char and coke, and temperature under a $\mathrm{CO}_{2}$ atmosphere at $1 \mathrm{~atm}$ is shown in Fig. 3. Here, open and solid triangles, and open and solid circles, and solid squares denote gasification rate of the biomass char carbonized at $800^{\circ} \mathrm{C}$ and $1000^{\circ} \mathrm{C}$ with the Cold conditions, that with $800^{\circ} \mathrm{C}$ and $1000^{\circ} \mathrm{C}$ with the Hot start conditions, and that of coke, respectively. The particle size was controlled with screening between $45-74 \mu \mathrm{m}$. The reaction rate of biomass char is higher than that of coke in couple of dozen times. The gasification rate of biomass char at $750^{\circ} \mathrm{C}$ is almost same value for any carbonization condition. The deviation of gasification rates of the biomass chars carbonized 800 and $1000^{\circ} \mathrm{C}$ increase with increasing in the temperature of reaction. The gasification rate of specimen carbonized in $800^{\circ} \mathrm{C}$ is higher than that in $1000^{\circ} \mathrm{C}$. The rate constant of gasification reaction of biomass char can be represented with straight-line approximation shown in Fig. 3, and those are

$$
k_{\mathrm{B}}=\exp (24.0-24400 / T)[1 / \mathrm{h}] \text {. }
$$

for the Cold start condition $800^{\circ} \mathrm{C}$,

$$
k_{\mathrm{B}}=\exp (24.6-25000 / T)[1 / \mathrm{h}] \ldots
$$

for the Hot start condition $800^{\circ} \mathrm{C}$,

$$
k_{\mathrm{B}}=\exp (17.8-17900 / T)[1 / \mathrm{h}] \ldots
$$

for the Cold start condition $1000^{\circ} \mathrm{C}$, and

$$
k_{\mathrm{B}}=\exp (14.3-14000 / T)[1 / \mathrm{h}] \text {. }
$$

for the Hot start condition $1000^{\circ} \mathrm{C}$.

Where $k_{\mathrm{B}}$ denotes rate constant of gasification reaction of biomass char. Activation energy for the biomass carbonized at 800 are $203 \mathrm{~kJ} / \mathrm{mol}$ and $208 \mathrm{~kJ} / \mathrm{mol}$, and at $1000^{\circ} \mathrm{C}$ are $149 \mathrm{~kJ} / \mathrm{mol}$ and $116 \mathrm{~kJ} / \mathrm{mol}$. Compared to the activation energy of coke particle; $223 \mathrm{~kJ} / \mathrm{mol}^{10)}$ the gasification energy of biomass char is lower value. Frequency factor of gasification of biomass char also lower than that of coke.

The influence of particle size on gasification was also measured. The measurement was carried out at $850^{\circ} \mathrm{C}$ in $\mathrm{CO}_{2}$ atmosphere. The sample was prepared with carbonizing at $1000^{\circ} \mathrm{C}$ with the Cold condition. The influence of size of the biomass char on the gasification rate is small. The duct structure of biomass char increases specific surface area, and thus the reaction rate of biomass char does
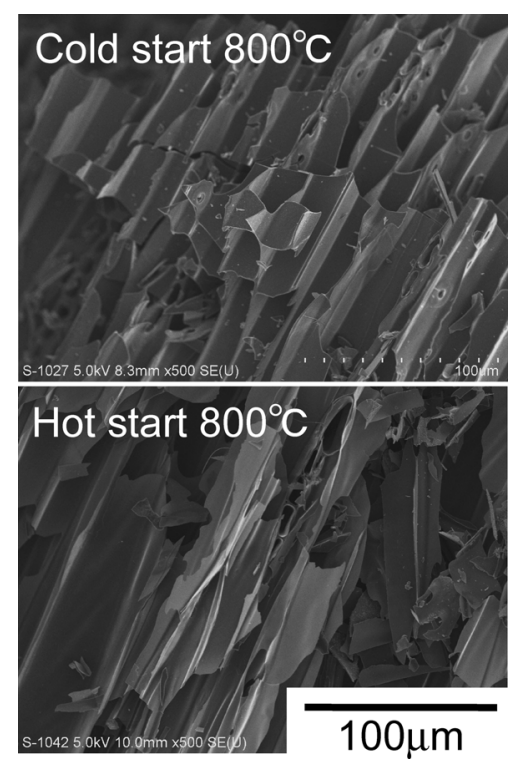

Fig. 4. SEM image of biomass char carbonized at $800^{\circ} \mathrm{C}$.

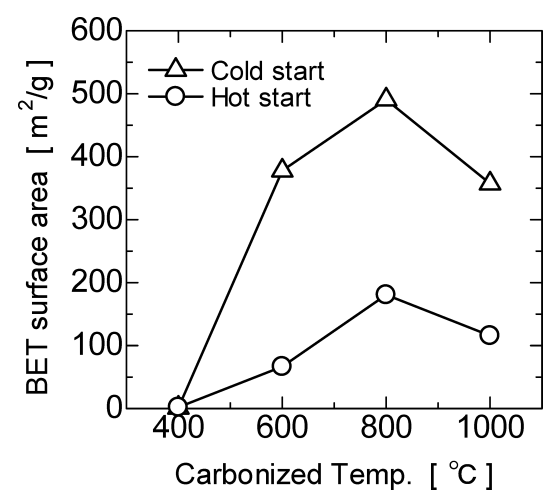

Fig. 5. Specific surface area of biomass char by $\mathrm{N}_{2}$ gas adsorption using the BET method.

not directly depend on the size of screening and appearance specific surface area.

\subsection{Micro Structure of Biomass Char}

The structures of biomass char carbonized at $800^{\circ} \mathrm{C}$ are shown in Fig. 4. Duct structure of wood remains in the biomass char. Thickness of the flat plate originated from the cell wall in wood is a couple of micrometers. The specific surface area depends on the structure, therefore that can not be evaluated by screening between $30-250 \mu \mathrm{m}$.

Specific surface area of biomass char by $\mathrm{N}_{2}$ gas adsorption using the BET method is shown in Fig. 5. The specific surface area depends on the heating condition, namely the Cold and Hot start conditions. Those of specimen carbonized at $800^{\circ} \mathrm{C}$ with the Cold condition is largest and about $500 \mathrm{~m}^{2} / \mathrm{g}$. Those of specimen carbonized at $800^{\circ} \mathrm{C}$ with the Hot condition also is largest in the sample for the Hot start condition. The results in Fig. 3 shows that the gasification reaction rate depends on the temperature of carbonization, and it is seen that the gasification reaction rate does not directly related to the specific surface area of biomass char by $\mathrm{N}_{2}$ gas adsorption using the BET method.

Relationship between pore volume of biomass char and its pore diameter is plotted in Fig. 6. Solid and open circles denote the Cold and Hot start conditions. The change of pore volume in the range of micro pore less than $10 \AA$ is 


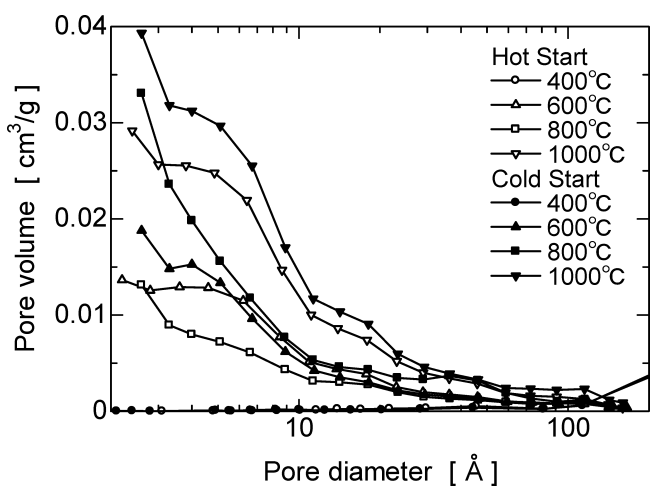

Fig. 6. Relationship between pore volume and diameter for biomass carbonized with various conditions.

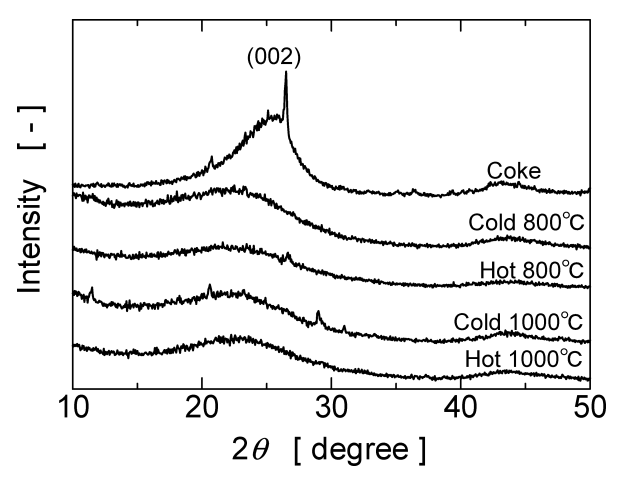

Fig. 7. XRD pattern of biomass char and coke.

observed on the biomass char carbonized over $600^{\circ} \mathrm{C}$. And that is rare on the biomass char carbonized at $400^{\circ} \mathrm{C}$. For both condition, the pore volume of sample with $1000^{\circ} \mathrm{C}$ is larger than others.

XRD pattern of biomass char and coke are shown in Fig. 7. The biomass chars were carbonized at 800 and $1000^{\circ} \mathrm{C}$ with the Hot and Cold start conditions. The biomass char of any carbonizing condition does not have significant pikes and those are different from the XRD pattern of coke which shows the peak of (002) refraction. The crystallization of biomass char is lower than that of coke. Relationship between the crystallization and carbonized temperature can not be seen. The relationship between the reactivity and crystalline of carbon had been investigated. ${ }^{14)}$ The crystalline of biomass char is not seem to make difference of reactivity between biomass chars with various preparation condition.

The features of biomass char are, 1) remaining the duct structure of wood, and the specific surface area can not be defined by screening, 2) compared to coke, much larger specific surface area of biomass char by $\mathrm{N}_{2}$ gas adsorption using the BET, 3 ) the pore of biomass char carbonized over $600^{\circ} \mathrm{C}$ is composed of micro pore, and 4) non-crystalline structure. The above features make biomass char more highly reactive than that of coke. The heat pattern of carbonization of biomass influences on the gasification reaction rate of that. However, the rate does not seem to be directory related to duct structure and crystalline. The activation energy and frequency factor of gasification for the sample carbonized at $1000^{\circ} \mathrm{C}$ are lower than those at $800^{\circ} \mathrm{C}$. Kawakami et al. reported that reaction rate is related to the amount of $\mathrm{CO}$ adsorption on the reducing
Table 2. Composition of iron ore used in the present study.

\begin{tabular}{cccccccc}
\hline \multicolumn{7}{c}{ Chemical composition of iron ore (mass\%) } \\
\hline $\mathrm{T}-\mathrm{Fe}$ & $\mathrm{FeO}$ & $\mathrm{SiO}_{2}$ & $\mathrm{CaO}$ & $\mathrm{Al}_{2} \mathrm{O}_{3}$ & $\mathrm{MgO}$ & $\mathrm{P}$ & $\mathrm{S}$ \\
67.5 & 0.21 & 1.31 & 0.01 & 0.73 & 0.01 & 0.033 & $<0.010$ \\
\hline
\end{tabular}

agent. ${ }^{12)}$ The activation energy and frequency factor might be influenced from complex of volume of micro pore, specific surface area, and composition. The composition of biomass char depends on the temperature of carbonization. Influence of volatile matter that composed of oxygen and hydrogen on the reaction should not be ignored.

\section{Reaction Behavior of the Carbon Iron Ore Compos- ite with Biomass Char}

\subsection{Experimental Apparatus}

The weight change of carbon iron ore composite with biomass char was measured using the thermogravimetric method. The apparatus is same to previous study, ${ }^{10)}$ therefore, that is briefly mentioned here. An electric resistance furnace connected to a proportional-integral-derivative (PID) controller with a thermocouple was used for the measurement. The temperature of the hot zone was maintained within $\pm 2 \mathrm{~K}$. Ar, $\mathrm{CO}$, and $\mathrm{CO}_{2}$ gas were mixed with mass flow controllers. A continuous flow of the gas mixture at $3.33 \mathrm{~mL} / \mathrm{s}$ was used to control the atmosphere. A high accuracy balance was set on the furnace, and a sample contained in a platinum basket was hung from the balance. The basket is made of a platinum mesh that does not disturb gas flow around the sample.

\subsection{Experimental Procedure}

The reducing agent of sample was prepared by grinding the biomass char into particles of sizes 25-38, 45-74, and $150-250 \mu \mathrm{m}$. MBR pellet feed within $45-74 \mu \mathrm{m}$ in diameter was used as iron ore. The composition of iron ore is listed in Table 2.

The $\mathrm{C} / \mathrm{O}$ molar ratio of the carbon iron ore composite was chosen to be $1 / 1$. Biomass char and iron ore powders with no binder were mixed uniformly and pressed in a 10$\mathrm{mm}$ die at $9.8 \mathrm{MPa}$ to form a tablet of the sample. The sample was suspended within the hot region in the furnace, and then, a gas was introduced in order to control the atmosphere inside the furnace. After the required gas composition of the atmosphere was reached, the sample was heated. The temperature inside the furnace was increased at a rate at $0.167^{\circ} \mathrm{C} / \mathrm{s}$ up to $1000^{\circ} \mathrm{C}$. Then, the temperature was maintained constant for $1800 \mathrm{~s}$ and then increased again at a rate at $0.083^{\circ} \mathrm{C} / \mathrm{s}$ up to $1200^{\circ} \mathrm{C}$. This heat pattern was determined on referring to the heating condition in a blast furnace.

\subsection{Experimental Results}

3.3.1. Influence of Heat Pattern of Carbonization of Biomass on the Reactivity of Carbon Iron Ore Composite with the Biomass Char

The relationship between the condition of carbonization of biomass char and the rate of reaction of the carbon iron ore composite is investigated in an argon atmosphere. In an inert gas atmosphere, coke and ore particles react with each 


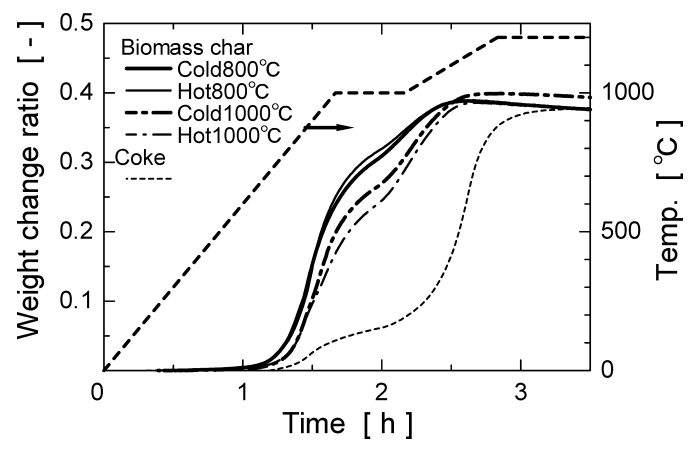

Fig. 8. Weight changes in the composite with the biomass char and coke.

other without the influence of the atmosphere outside the composite. The particle size of biomass char was controlled with in $45-74 \mu \mathrm{m}$. The weight changes in the composite with the biomass char and coke for the $\mathrm{C} / \mathrm{O}$ ratio of $1 / 1$ are shown in Fig. 8. Where, broken line denotes temperature. Compared to the composite with coke, that with biomass char begins weight changing in lower temperature. The reaction finishes at about around $2 \mathrm{~h}$ in the experimental time that is earlier than the reaction of the composite with coke. Reaction rate of the composite with biomass char carbonized at $800^{\circ} \mathrm{C}$ is slightly faster than that at $1000^{\circ} \mathrm{C}$. The order of gasification rate of biomass char is not directly related the reaction constant of gasification reaction of biomass char shown in Fig. 3. Therefore, it can be said the reaction of composite is not limited only the gasification reaction of biomass char.

\subsubsection{Influence of Particle Size of Biomass Char and Iron Ore on Reaction Rate of Carbon Iron Ore Compos- ite}

The relationship between the screening size of the biomass char and the rate of reaction of the carbon iron ore composite is investigated in an argon atmosphere. Biomass char carbonized at $800^{\circ} \mathrm{C}$ with the Hot start condition was ground into particles of sizes 25-38, 45-74, and 150$250 \mu \mathrm{m}$. The weight changes in the composite for the $\mathrm{C} / \mathrm{O}$ ratio of 1/1 are shown in Fig. 9. The reaction behaviors of sample are similar each other, however, the influence of size of biomass char on the gasification rate is observed at stage of $\mathrm{Fe}-\mathrm{FeO}$ reduction, namely, over 0.15 in weight change ratio. Meanwhile, the influence of particle size of biomass char on gasification rate is not remarkable. The results show that the reaction rate decreases with increasing particle size of the biomass char. It will be discussed in following part.

\subsubsection{Influence of Gas Phase outside Composite}

Figure 10 shows the weight change ratio of the composite in a $\mathrm{CO} / \mathrm{CO}_{2}$ atmosphere compared to that in Ar. The $\mathrm{CO} / \mathrm{CO}_{2}$ ratio is controlled to be $1 / 1$. The $\mathrm{C} / \mathrm{O}$ ratio in the composite is constant at $1 / 1$. Bold solid and broken lines represent the composite with biomass char in $\mathrm{Ar}$ and $\mathrm{CO} / \mathrm{CO}_{2}$, respectively. The weight change ratio of the composite with coke was compared and represented as thin broken line. In the $\mathrm{CO} / \mathrm{CO}_{2}$ atmosphere, the reaction of carbon iron ore composite with biomass char and coke begin at about $400^{\circ} \mathrm{C}$. At lower temperature, the reducing agent and ore react with $\mathrm{CO}$ and $\mathrm{CO}_{2}$ outside the composite. Com-

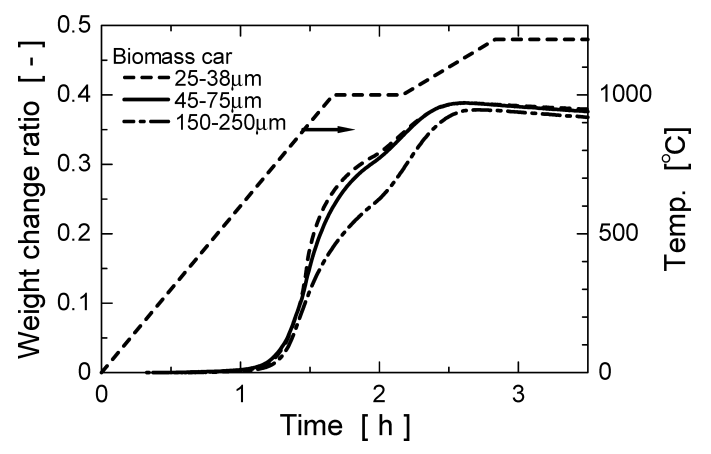

Fig. 9. Influence of screening size of the biomass char on reaction rate of the carbon iron ore composite.

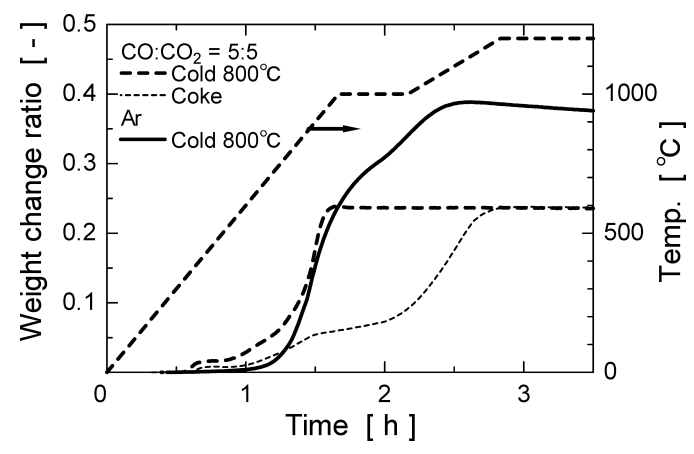

Fig. 10. Weight change ratio of the carbon iron ore composite with biomass char in a $\mathrm{CO} / \mathrm{CO}_{2}$ atmosphere.

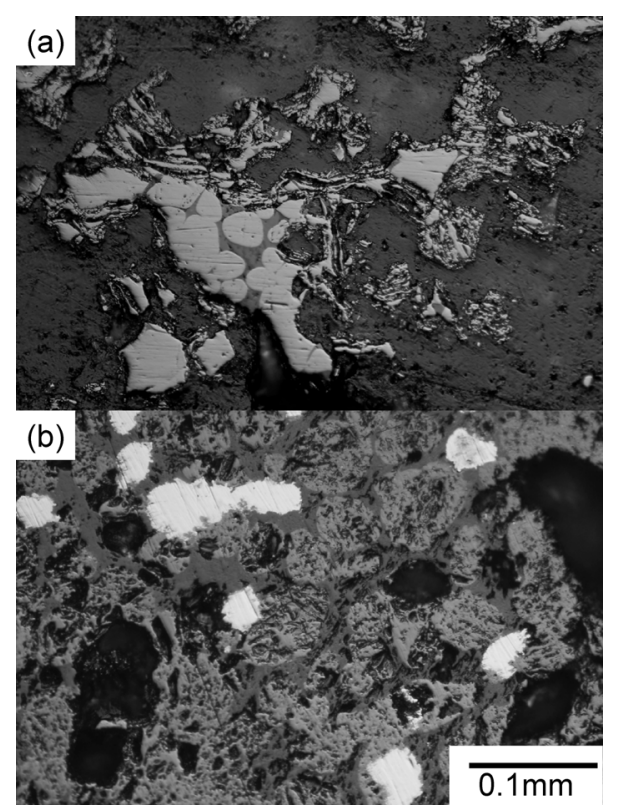

Fig. 11. Cross section of sample after reaction in Ar. (a) With biomass char, (b) with coke.

pared to the composite with coke, the reaction rate of that with biomass char is faster. Gasification reaction of biomass char with $\mathrm{CO}_{2}$ outside is more active than that of coke in the composite.

Figure 11 shows cross section of the specimen reacted in the $\mathrm{CO} / \mathrm{CO}_{2}$ atmosphere after reaction. (a) and (b) represent the carbon iron ore composite with biomass char and coke, respectively. (a) bright and dark gray regions are wüstite phase and resin used for fixing, respectively. The dark gray region represents the vacancy of the composite, the com- 
posite after reaction is composed of porous wüstite. (b) white and gray regions are metallic iron and wustite. Compared to (b), the porosity of (a) is high. The vacancy would enhances the exchanging of gas phases inside and outside the composite through the surface of composite. Reactivity of biomass char and ore in the composite with biomass char with the gas outside were higher than that the composite with coke.

The biomass char enhances the reaction of that with atmosphere outside the composite in lower temperature range. The gas exchange between outside and inside the composite can be controlled by controlling production method of the composite, namely, density, texture of surface and binders. Then the gas composition in the blast furnace affect on the reaction ratio and composition of gas phase in composite. The method to provide the composite should be discussed for the actual usage in the blast furnace.

\section{Analysis of Reaction of the Composite with a Reac- tion Model}

\subsection{Reaction Model of Carbon Iron Ore Composite with Biomass Char}

The concept of the proposed reaction model of the carbon iron ore composite had been reported. ${ }^{10)}$ Therefore, that is briefly mentioned here. The composite is composed of fine powder of biomass char and iron ore, and vacancy between them. Considering the conditions of temperature in the blast furnace, some presumptions are employed. There is no distribution of pressure, temperature, and composition of gas phase inside the composite. The reaction ratios of the carbon and the iron ore are uniform in the composite. The reaction between the reduction of iron ore and the gasification of reducing agent occurs through the gas phase in the vacancy. The mole number of the gas inside composite increases with the gasification. In order to maintain a constant pressure inside the composite, the gas generated in the composite would flow out through the surface. The chemical reactions considered in the proposed model are reduction of hematite, magnetite and wüstite and gasification reaction of biomass char.

The chemical reactions considered in the proposed model are

$$
\mathrm{C}(\mathrm{s})+\mathrm{CO}_{2}(\mathrm{~g})=2 \mathrm{CO}(\mathrm{g})
$$

$$
\begin{gathered}
3 \mathrm{Fe}_{2} \mathrm{O}_{3}(\mathrm{~s})+\mathrm{CO}(\mathrm{g})=2 \mathrm{Fe}_{3} \mathrm{O}_{4}(\mathrm{~s})+\mathrm{CO}_{2}(\mathrm{~g}) \\
\mathrm{Fe}_{3} \mathrm{O}_{4}(\mathrm{~s})+\mathrm{CO}(\mathrm{g})=3 \mathrm{FeO}(\mathrm{s})+\mathrm{CO}_{2}(\mathrm{~g}) \ldots
\end{gathered}
$$

and

$$
\mathrm{FeO}(\mathrm{s})+\mathrm{CO}(\mathrm{g})=\mathrm{Fe}(\mathrm{s})+\mathrm{CO}_{2}(\mathrm{~g}) .
$$

The reaction ratio of them and the concentration of $\mathrm{CO}$ and $\mathrm{CO}_{2}$ in the gas phase are determined by integrating each differential equation of reaction rate, Eqs. (5)-(8). Influence of size and reaction rate of iron ore were installed to Eq. (5) as the reaction rate of biomass char. Reaction rate of biomass char $R_{\mathrm{c}}$ was represented as,

$$
\frac{d R_{\mathrm{C}}}{d t}=k_{\mathrm{b}} \cdot\left(P_{\mathrm{CO}_{2}}-P_{\mathrm{CO}_{2}}^{*}\right) \cdot \frac{1}{d} \cdot f_{\mathrm{d}} \cdot f_{\mathrm{CO}} \cdot\left(1-R_{\mathrm{C}}\right)^{2 / 3}
$$

where, $f_{\mathrm{d}}$, and $f_{\mathrm{CO}}$ denote the effect of the size of the coke particles and factor of $\mathrm{CO}$ in the gas phase on reaction rate, respectively. $t, d, P_{\mathrm{CO}_{2}}$, and $P_{\mathrm{CO}_{2}}^{*}$ are time, diameter of biomass char particle, the equilibrium partial pressure of $\mathrm{CO}_{2}$ and that in $\mathrm{aO} / \mathrm{CO}_{2}$ atmosphere saturated with carbon.

Reduction rate of hematite, magnetite, and wüstite are represented as,

$$
\frac{d R_{\text {ore }}}{d t}=\frac{6 \cdot \mathrm{M}_{\mathrm{FeO}_{1.5}}}{\pi \cdot d_{\text {ore }}^{3} \cdot \rho_{\mathrm{FeO}_{1.5}}} \cdot v_{\text {ore }}
$$

where $v_{\text {ore }}, d_{\text {ore }}, \mathrm{M}_{\mathrm{FeO}_{1.5}}$, and $\rho_{\mathrm{FeO}_{1.5}}$ denote reduction rate of iron ore, the diameter of the ore particles, the molar weight, and the specific gravity of $\mathrm{FeO}_{1.5}$. Ore means the reaction between hematite-magnetite, magnetite-wustite, ore wustite-iron.

The thermogravimetric method was employed to measure reduction rate of MBR pellet feed in $\mathrm{CO}$ gas at $1 \mathrm{~atm}$. The weight changing rates were installed to the present model.

$$
\begin{aligned}
\frac{d n_{\mathrm{CO}}}{d t}= & \left(n_{\mathrm{C}} \frac{d R_{\mathrm{C}}}{d t}\left(2-X_{\mathrm{CO}}\right)-n_{\mathrm{O}} \frac{d R_{\text {ore }}}{d t}\right) \\
& +P^{\circ} \cdot S \cdot\left(k_{\mathrm{CO}}^{*}\left(X_{\mathrm{CO}}^{\text {out }}-X_{\mathrm{CO}}\right)\left(1-X_{\mathrm{CO}}\right)\right. \\
& \left.-k_{\mathrm{CO}_{2}}^{*}\left(X_{\mathrm{CO}_{2}}^{\text {out }}-X_{\mathrm{CO}_{2}}\right) \cdot X_{\mathrm{CO}}^{\text {out }}\right) \cdots \cdots \cdots \cdots
\end{aligned}
$$

and

$$
\begin{aligned}
& \frac{d n_{\mathrm{CO}_{2}}}{d t}=\left(n_{\mathrm{C}} \frac{d R_{\mathrm{C}}}{d t}\left(-1-X_{\mathrm{CO}_{2}}\right)+n_{\mathrm{O}} \frac{d R_{\text {ore }}}{d t}\right) \\
& +P^{\circ} \cdot S \cdot\left(k_{\mathrm{CO}_{2}}^{*} \cdot\left(X_{\mathrm{CO}_{2}}^{\text {out }}-X_{\mathrm{CO}_{2}}\right)\left(1-X_{\mathrm{CO}_{2}}^{\text {out }}\right)\right. \\
& \left.-k_{\mathrm{CO}}^{*}\left(X_{\mathrm{CO}}^{\text {out }}-X_{\mathrm{CO}}\right) \cdot X_{\mathrm{CO}_{2}}\right) \text {. }
\end{aligned}
$$

where $n_{i}, X_{i}, X^{\text {out }}, P^{0}, S$ and $k_{i}^{*}$ denote number of mole of $i$, mole fraction of $i$, mole fraction of $i$ outside the composite, total pressure, surface area, and mass transfer coefficient of $i$.

Weight change of the carbon iron ore composite with biomass char carbonized at $800^{\circ} \mathrm{C}$ with the Hot condition was derived by the model. The calculation and experimental results are shown in Fig. 12. The reactions begin at

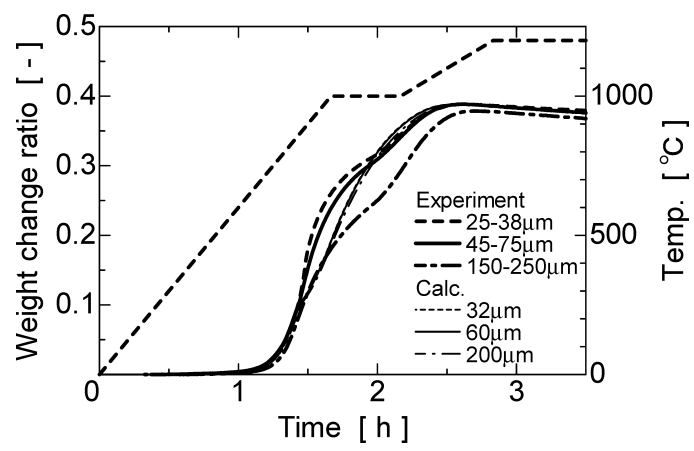

Fig. 12. Weight change of the carbon iron ore composite derived from the present experiment and model. 
about $550^{\circ} \mathrm{C}$ in the simulation and the experiment, and the reaction rates agree with each other up to 0.2 in weight changing ratio. The reaction rate with smaller size of biomass char is slightly faster. Reduction of iron ore in the carbon iron ore composite limits the reaction and that causes the decreasing of the weight changing rate over 0.2 . Initial reaction is well predicted by the model in the temperature and weight change. That means direct reduction reaction between biomass char and ore was not observed and influence of direct reaction is much smaller than indirect one through gas phase. The deviations between experiment and simulation are seen over 0.2 in weight changing ratio. The influence of size of biomass char on gasification reaction is small, however influence of size is seen for the experimental value. Particle size of ore was controlled within 45-74 $\mu \mathrm{m}$, the reactivity of ore in the composite should be same for all specimen. Therefore, the condition of contact between ore and reducing agent might influence on the total reaction of carbon iron ore composite. Variation of particle size changes contact condition between particles, and that would influence on the reactivity for the carbon iron ore composite with biomass char. It is known that the catalytic reaction between $\mathrm{Fe}-\mathrm{FeO}$ enhances gasification reaction of carbon. ${ }^{15)}$ The catalytic effect of iron and variation of contact area with changing particle size of biomass char may cause the difference of reaction behavior in the present experiment.

It should be noted that the model shows good agreement to the experimental result up to the stage of reduction of wüstite without parameter fitting, and the rate limit reactions are caused from gasification of biomass in lower temperature and both of gasification and reduction of iron ore in higher temperature. In order to increase the accuracy of reaction model, the effect of $\mathrm{Fe}-\mathrm{FeO}$ reaction on the gasification reaction of carbon should be investigated and installed in to the model.

\subsection{Analysis of Gas Composition in the Composite by the Reaction Model}

Gas is generated with the reaction inside the carbon iron ore composite. The gas flows out from the surface of the composite and influences on the composition of gas in the blast furnace. The composition of gas inside the composite calculated by the model is plotted on the phase diagram of $\mathrm{Fe}-\mathrm{O}$ as shown in Fig. 13. Here, $8 \mathrm{~mm}$ was employed as diameter of the composite. Heat pattern is same to the experimental condition. Bold and thin lines are composition of gas inside the composite with biomass and coke of 45-74 $\mu \mathrm{m}$, respectively. Solid, broken and chain lines denote the reaction in inert gas, $\mathrm{CO} / \mathrm{CO}_{2}=7 / 3$, and $\mathrm{CO} / \mathrm{CO}_{2}=5 / 5$ atmosphere, respectively. Thin dashed line represents gas composition equilibrated with carbon and composition of gas atmosphere. Concentration of $\mathrm{CO}$ inside the composite changes with increasing in temperature.

The lines are inflected at the border between $\mathrm{FeO}-\mathrm{Fe}_{3} \mathrm{O}_{4}$. However, that with coke follows the equilibration between $\mathrm{Fe}-\mathrm{FeO}$, that with biomass char deviates from the equilibrium line. The behavior related to the equilibration of iron ore indicates that the composition of gas is controlled by the reduction of iron ore. If the gasification reaction is much faster than the reduction of iron ore, the gas would be

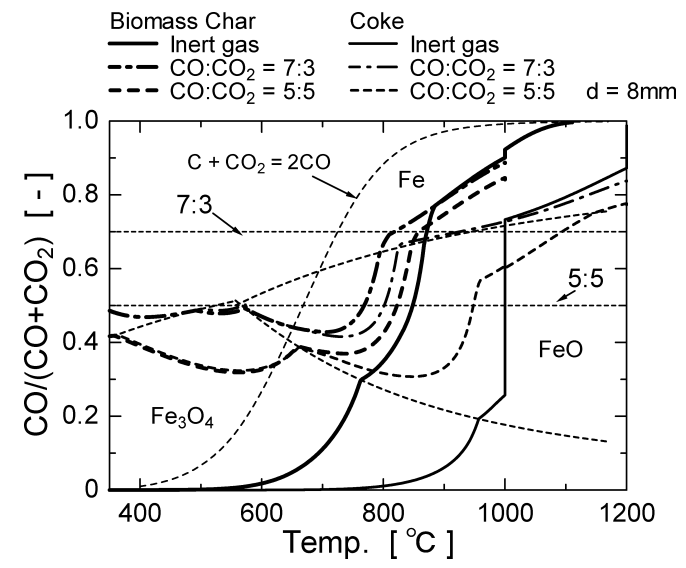

Fig. 13. Gas compositions generated from carbon iron ore composite with biomass char and coke.

on the equilibrium line of $\mathrm{CO}, \mathrm{CO}_{2}$ and $\mathrm{C}$.

In inert gas, the curve of gas composition with the biomass char is much lower than that with coke in temperature, and near to the Boudouard equilibrium line. It can be said that the position of the line with biomass char is influenced from the high reactivity of biomass char. At the stage of $\mathrm{Fe}-\mathrm{FeO}$ equilibration the composition of gas is deviate from the equilibrium composition of $\mathrm{Fe}-\mathrm{FeO}$, that mean gasification reaction of biomass char and reduction reaction of iron ore is comparable. The reaction rate of carbon iron ore composite is controlled from both of the reactions.

In $\mathrm{CO} / \mathrm{CO}_{2}$ atmosphere, the composition of gas inside composite is influenced from the outside gas atmosphere. In the lower temperature range, since the gas outside is likely to transfer to the inside of the composite due to the inactive gasification of carbon, the gas composition is independent on reducing agent. However, in comparison with coke, reactivity of biomass char is much higher than that of coke, then the gas composition with biomass char is nearer to the $\mathrm{CO}, \mathrm{CO}_{2}$, and $\mathrm{C}$ equilibration. In the case of the composite with biomass char, it is considered that the composite reacts as an independent microreactor in the blast furnace.

\subsection{Behavior of Carbon Iron Ore Composite with Bio- mass Char in the Blast Furnace}

It is shown in Figs. 8 and 10, that the carbon iron ore composite with biomass char reacts in lower temperature than that with coke. Temperature of the thermal reserve zone is determined by the balance of heat supply from the gas phase, and endothermic reaction and sensible heat of burden. High reactivity of burden enhances the endothermic reaction and would decrease the temperature of the thermal reserve zone. The carbon iron ore composite may replace some parts of coke and iron ore. Decreasing the thermal reserve zone temperature in $10^{\circ} \mathrm{C}$ causes an reduction of reducing agent ratio about $3 \mathrm{~kg} / \mathrm{thm} .{ }^{1)}$ Meanwhile, the carbon in the composite is easily reacted with $\mathrm{CO}_{2}$ and generates $\mathrm{CO}$ in upper part of the blast furnace, that might decrease the gas utilization efficiency of ironmaking process. Gas composition transitions in the composite with various composite size, namely, 4,8 , and $16 \mathrm{~mm}$ are shown in Fig. 14. Thin lines and solid line denote in $\mathrm{CO}$ and in inert gas. Gas composition in the composite in $\mathrm{CO} / \mathrm{CO}_{2}$ at- 


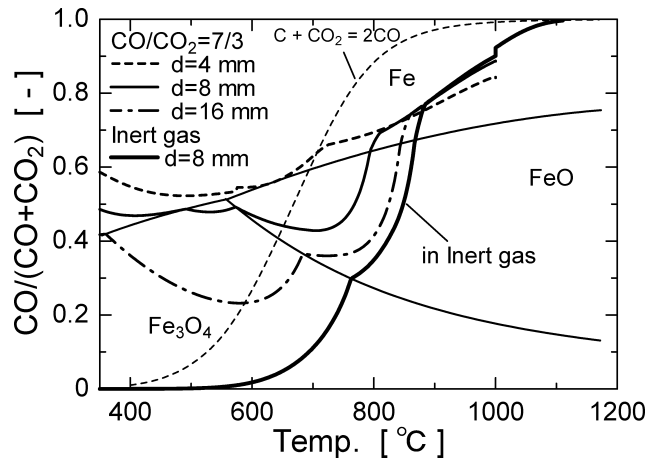

Fig. 14. Gas compositions generated from iron carbon ore composite with biomass char in $\mathrm{CO} / \mathrm{CO}_{2}$.

mosphere changes with size of particle. The gas composition in inert represents that the gas composition inside and reaction rate of ore and biomass char are not influenced from the gas outside. Gas composition inside composite shifts to that outside with an decrease in the size of composite. Reactivity of composite and composition of gas generated from the composite can be controlled with changing size of composite. The role of the carbon iron ore composite, and the influence of enhancement of reactivity of that would be derived in a total blast furnace simulator with the present reaction model.

\section{Conclusions}

The reaction and reducing behavior of carbon iron ore composite with biomass char was investigated. The analysis with a reaction model of the carbon iron ore composite based on a lumped system with the reaction rate of biomass char was carried out, and the calculation result was compared to the result of experiment. The following results are obtained:

(1) The gasification reaction rate of biomass char is faster than that of coke in couple of dozen times. The carbonization condition of biomass has a great influence on the biomass char properties like specific surface area.

(2) The biomass char remains the duct structure of wood that cause its high reactivity. Since of the structure, the specific surface area can not be defined by screening. The reactivity of biomass with $\mathrm{CO}_{2}$ is indirectly related to BET surface area.
(3) The reduction of the composite begins at about $550^{\circ} \mathrm{C}$. The reactivity of the carbon iron ore composite with biomass char is remarkable faster than that with coke.

(4) The reaction rate of carbon iron ore composite with high reactive reducing agent is controlled from both reaction rate of carbon gasification and iron ore reduction.

(5) The present model of carbon iron ore composite with biomass char shows good agreement to the experimental result up to the stage of reduction of wüstite.

(6) The structure of the composite like diameter of the composite has an influence on the reaction behavior through the gas exchange effect with the gas phase outside composite. In the case of the composite with biomass char, the influence of the outside atmosphere is relatively smaller than coke.

\section{Acknowledgement}

Financial support from ISIJ Research Promotion Grant is gratefully acknowledged.

\section{REFERENCES}

1) T. Ariyama, R. Murai, J. Ishii and M. Sato: ISIJ Int., 45 (2005), 1371.

2) Y. Ujisawa, K. Nakano, Y. Matsukura, K. Sunahara, S. Komatsu and T. Yamamoto: Tetsu-to-Hagané, 92 (2006), 1015.

3) S. Nomura, H. Kitaguchi, K. Yamaguchi and M. Naito: ISIJ Int., 47 (2007), 245.

4) A. Kasai, M. Naito, Y. Matsui and Y. Yamagata: Tetsu-to-Hagané, 89 (2003), 1212

5) Y. Matsui, M. Sawayama, A. Kasai, Y. Yamagata and F. Noma: ISIJ Int., 43 (2003), 1904.

6) F. Meng, Y. Iguchi and S. Hayashi: Tetsu-to-Hagané, 63 (2002), 479.

7) R. J. Fruehan: Metal. Trans. B, 8B (1977), 279.

8) X. Zhang, R. Takahashi and J. Yagi: Tetsu-to-Hagané, 81 (1995), 1043.

9) Y. Ueki, T. Maeda, M. Shimizu, Y. Matsui and A. Kasai: Tetsu-toHagané, 89 (2003), 1205.

10) S. Ueda, K. Yanagiya, K. Watanabe, T. Murakami, R. Inoue and T. Ariyama: ISIJ Int., 49 (2009), 827.

11) S. Ueda, R. Inoue and T. Ariyama: Tetsu-to-Hagané, 94 (2008), 468.

12) M. Kawakami, T. Ohyabu, Y. Mizutani, T. Takenaka and S. Yokoyama: Tetsu-to-Hagané, 89 (2003), 581.

13) Japan Institute of Energy (Ed.): Biomass hand book, OHMSha, Tokyo, (2003), 117.

14) Y. Kashiwaya and K Ishii: ISIJ Int., 31 (1991), 440.

15) Y. Kashiwaya, S. Nakaya and K. Ishii; Tetsu-to-Hagané, 77 (1991), 759. 